\title{
INVESTIGATION OF BIOFLOCCULANT AS DEWATERING AID IN SLUDGE TREATMENT
}

\author{
Mohammed Saedi Jami*, Maizirwan Mel, Aysha Ralliya Mohd Ariff, \\ AND QABAS MARWAN ABDULAZEEZ \\ Department of Biotechnology Engineering, Faculty of Engineering, \\ International Islamic University Malaysia, \\ Jalan Gombak, 53100 Kuala Lumpur, Malaysia. \\ *Corresponding author: saedi@iium.edu.my
}

(Received: 15 th Sept 2016; Accepted: $5^{\text {th }}$ May 2017; Published on-line: $1^{\text {st }}$ June 2018)

https://doi.org/10.31436/iiumej.v19i1.735

\begin{abstract}
Sludge treatment is one of the most important and expensive steps in water and wastewater treatment plants. Chemical conditioners such as polyaluminum chloride, aluminum sulfate, Fenton's reagent, gypsum, and polyacrylamide can produce byproducts that cause health and environmental problems. Moringa oleifera (MO) seeds can be used as a natural alternative to chemical conditioners. The bioactive materials have to be extracted from MO seeds for better performance. In this study, the treatment methods of MO seeds were the bioactive extraction by $\mathrm{NaCl}(1 \mathrm{M})$ and oil extraction by hexane solvent, as well as the untreated (crude) seeds powder. Synthetic sludge samples were prepared using kaolin suspension $(5 \% \mathrm{w} / \mathrm{v})$. The most effective coagulant-form was determined based on the values of settling velocity $\left(V_{\mathrm{s}}\right)$ and sludge volume index (SVI). Results showed that extraction by $\mathrm{NaCl}$ gave the best results of $0.41 \mathrm{~cm} / \mathrm{min}$ of settling velocity and $63.39 \mathrm{ml} / \mathrm{g}$ of SVI. A SVI value greater than $150 \mathrm{ml} / \mathrm{g}$ indicates poor settling qualities whereas the control sludge of the current study was $100 \mathrm{ml} / \mathrm{g}$. The most effective coagulant-form was optimized with respect to three process conditions: MO seeds dosage, mixing speed, and contact time. The experiments were designed using 2 Level FactorialDesign by Design-Expert software. The optimum process conditions were seeds dosage of $3246 \mathrm{mg} / \mathrm{l}$, mixing speed of $102 \mathrm{rpm}$, and mixing time of 29 min. MO seeds can be considered as a natural coagulant that can be used as main sludge conditioner.
\end{abstract}

ABSTRAK: Rawatan kotoran mendapan adalah salah satu rawatan penting dan termahal dalam merawat air dan sisa kumbahan loji. Perapi kimia seperti poli-aluminium klorida, aluminium sulfida, reagen Fenton, gipsum, dan poli-akrilamida menghasilkan sisa, di mana memberi kesan kepada kesihatan dan alam sekitar. Benih Moringa oleifera (MO) boleh digunakan sebagai bahan ganti semula jadi kepada perapi kimia. Bahan bio-aktif perlu diekstrak daripada benih MO bagi memberi kesan terbaik. Dalam kajian ini, kaedah rawatan menggunakan benih $\mathrm{MO}$ adalah dari ekstrak bio-aktif $\mathrm{NaCl}(1 \mathrm{M})$ dan ekstrak minyak dari bahan larut hexane, serta serbuk benih tidak dirawat (mentah). Sampel sintetik kotoran mendapan disediakan dengan menggunakan ampaian kaolin $(5 \% \mathrm{w} / \mathrm{v})$. Bentuk kogulan yang paling efektif didapati berdasarkan nilai halaju malar $\left(V_{\mathrm{s}}\right)$ dan indeks ketumpatan kotoran mendapan (SVI). Keputusan menunjukkan ekstrak $\mathrm{NaCl}$ memberi keputusan terbaik pada halaju malar $0.41 \mathrm{~cm} / \mathrm{min}$ dan bacaan pada SVI $63.39 \mathrm{ml} / \mathrm{g}$. Nilai SVI lebih besar daripada $150 \mathrm{ml} / \mathrm{g}$ menunjukkan kualiti kadaran malar kurang baik berbanding $100 \mathrm{ml} / \mathrm{g}$ kajian kawalan semasa kotoran mendapan. Bentuk kogulan yang paling efektif telah dioptimumkan pada tiga keadaan proses: dos benih MO, halaju campuran dan tempoh campuran. Eksperimen dibentuk menggunakan 2 Level FactorialDesign daripada perisian Design-Expert. Keadaan optimum proses adalah pada $3246 \mathrm{mg} / \mathrm{l}$ dos benih, $102 \mathrm{rpm}$ halaju campuran, dan tempoh campuran selama 29 min. Benih MO 
boleh di kategori sebagai kogulan semula jadi dan boleh digunakan sebagai perapi utama bagi kotoran mendapan.

KEYWORDS: sludge treatment; Moringa oleifera; dewatering; environmental friendly

\section{INTRODUCTION}

The major aim of wastewater treatment is to eliminate or minimize the dangerous effects on public health and the environment. Various types of contaminants should be removed from wastewater, such as suspended solids, biodegradable matter (organic compounds), inorganic solids, nutrients, metals and pathogenic microorganisms. In order to remove these contaminants, wastewater treatment requires physical, chemical, and biological processes. The physical and chemical processes are usually used for potable water treatment while the biological process is mainly for wastewater treatment due to the high organic concentration [1].

Sludge can be generated from settling tanks during primary, secondary and advanced treatment processes. These processes separate the suspended solids and colloidal materials from the liquid body and produce sludge at high solids content of $0.25-12 \%$ by weight [2]. With the high range of solid concentration, sludge management is considered to be one of the most difficult and expensive processes in wastewater treatment [3]. Sludge should pass through many treatment stages before disposal, which may include thickening, anaerobic and aerobic digestion, and dewatering. Thickening and dewatering processes reduce the content of water and increase solid concentration. The dewatering process occurs during use of mechanical systems such as belt filter presses, centrifuges or gravity drainage, and evaporation in sand drying beds. Usually, mechanical dewatering equipment is expensive and consumes high amounts of energy [1]. Dewatering by chemical conditioners is very efficient and it is used worldwide, but has negative impacts on human health and the environment associated with the formation of byproducts [4].

Moringa oleifera (MO) seed is a natural polymer and a highly biodegradable coagulant that is affordable and environmentally friendly. The seeds have potential to be used as sludge conditioner for thickening and dewatering. These seeds were investigated for the removal of turbidity, heavy metal ions, color, and as disinfectant [5-8]. MO seeds with a cationic property are expected to be efficient in adsorbing the sludge particles and neutralizing the charge on their surface resulting in effective coagulation and elimination of the hazardous impacts on human health and the environment.

\section{MATERIALS AND METHODS}

\subsection{Materials and Equipment}

Dry MO seeds were imported from Genius Herbs Company, India. Kaolin suspension was used as the synthetic sludge, which was bought from R\&M Chemicals Sdn Bhd. NaCl from $\mathrm{HmbG}$ was used for bioactive material extraction. A kitchen blender was used for seed blending. Soxhlet apparatus was used for oil extraction from MO seeds. Jar test apparatus was used for process condition optimization. Vacuum filtration with a Buchner-funnel and Whatman-filter-paper \#3 were used to determine TSS. A $500 \mathrm{ml}$ graduated cylinder and stopwatch were used for the sludge volume index (SVI). Other laboratory equipment included a magnetic stirrer, a drying oven, and a weighing balance. 


\subsection{Methods}

\subsubsection{Preparation of Sludge Sample}

Sludge samples were prepared from kaolin suspension by adding $5 \mathrm{~g}$ of kaolin to 1 liter of distilled water in order to generate a sludge with $5 \%$ total solids $(\mathrm{w} / \mathrm{v})$. The sample was mixed at a speed of $200 \mathrm{rpm}$ for about 10 min using jar test apparatus $[9,10]$.

\subsubsection{Preparation of Different Forms of MO Seeds}

The shelled MO seeds were ground by kitchen blender and screened using a $212 \mu \mathrm{m}$ sieve. Three types of MO seeds were prepared as natural conditioners: Crude MO seeds, defatted $\mathrm{MO}$ seeds, and $\mathrm{MO}$ extracted by $\mathrm{NaCl}(1 \mathrm{M})$. All coagulant forms were used as an aqueous solution. The crude MO seed powder was used for coagulation without any treatment after mixing with distilled water. The second type was oil-extracted by hexane solvent using $10 \mathrm{~g}$ of MO seed powder with $200 \mathrm{ml}$ of hexane. Soxhlet extraction apparatus was used for oil extraction $[6,9,11]$.

The first two types (crude and defatted MO seed powder) were mixed with distilled water by adding $10 \mathrm{~g}$ of powder into 1 liter distilled water, then, the mixture was rapidly mixed for $10 \mathrm{~min}$ to extract the bioactive materials. Finally, the mixture was filtered using filter paper and the insoluble powder particles were removed.

For salt extraction, $58.44 \mathrm{~g}$ of $\mathrm{NaCl}$ was added to 1 liter of distilled water and mixed using jar test apparatus. The $\mathrm{NaCl}$ solution was mixed with $10 \mathrm{~g}$ of crude $\mathrm{MO}$ seeds for 10 min. Finally, the mixture was filtered using filter paper and the insoluble powder particles were removed [12].

\subsubsection{Experimental Procedures}

Jar test apparatus was used for sludge conditioning using six beakers of 1 liter capacity. The selection of the most effective coagulant form was determined through the sludge volume index (SVI) and settling velocity $\left(V_{\mathrm{s}}\right)$. Experiments were run at MO dosages of 2000, 4000, and $6000 \mathrm{mg} / \mathrm{l}$. The most effective coagulant form was optimized under different process conditions.

\subsection{Design of Experiment and Statistical Analysis}

\subsubsection{Process Conditions Optimization}

The design of experiment (DOE) was used to optimize the three process conditions: conditioner dosage, mixing speed and contact time, and the settling velocity $(\mathrm{cm} / \mathrm{min})$ was used as the response. The primary ranges were determined using one-factor-at-a-time (OFAT) preliminary optimization. The experimental results were analyzed using DesignExpert software v10 (Stat-Ease Inc.). The variables and their range of levels for the experimental design are listed in Table 1. Experimental design for process conditions optimization is listed in Table 2.

Table 1: Ranges of levels for experiment parameters

\begin{tabular}{llccc}
\hline \multirow{2}{*}{ Parameters } & \multirow{2}{*}{ Unit } & \multicolumn{3}{c}{ Range of levels } \\
\cline { 3 - 5 } & & -1 & 0 & +1 \\
\hline Concentration of MO seeds & $\mathrm{mg} / \mathrm{l}$ & 500 & 3250 & 6000 \\
Mixing speed & $\mathrm{rpm}$ & 50 & 100 & 150 \\
Contact time & $\mathrm{min}$ & 5 & 17.5 & 30 \\
\hline
\end{tabular}




\subsubsection{Settling Velocity (Vs) Measurement}

Settling velocity $\left(V_{\mathrm{s}}\right)$ was used to determine the most effective coagulant form together with SVI. $V_{\mathrm{s}}$ was also used as a response for process condition optimization. $V_{\mathrm{s}}$ was measured using graduated beakers and a stopwatch and one reading was recorded each 1 $\min$ for $30 \mathrm{~min}$. Then, the settling rate was determined by plotting the $V_{s}$ values versus the time, and the slope of the curve represents the final settling velocity [10].

\subsubsection{Sludge Volume Index (SVI) Measurement}

The sludge volume index (SVI) is the volume of one gram of sludge after $30 \mathrm{~min}$ of settling. The SVI was determined by placing the samples into cylinder beakers and measuring the settled sludge after $30 \mathrm{~min}$ [10]. The values of SVI was determined using Eqn. (1):

$$
\text { SVI }=\frac{\text { settled sludge volume }(\mathrm{ml} / \mathrm{l}) \times 1000(\mathrm{mg} / \mathrm{g})}{\operatorname{TSS}(\mathrm{mg} / \mathrm{l})}
$$

\subsubsection{ANOVA Analysis}

The results were analyzed using analysis of variance (ANOVA) approach and $P$-value. The significance of each coefficient was analyzed by comparing the obtained $P$-value with 0.05 (95\% confidence level). The model is significant if $P$-value was less than 0.05 [13]. The optimum $V_{\mathrm{s}}$ value was obtained using a regression model equation, and 2D and 3D plot analysis.

\section{RESULTS AND DISCUSSION}

\subsection{The Most Effective Coagulant Form}

Settling rates were estimated from the slope of the straight-line portion of the plot interface height versus settling time. From the results obtained, $V_{\mathrm{s}}$ for MO salt extract was the highest settling velocity of $0.41 \mathrm{~cm} / \mathrm{min}$ at $4000 \mathrm{mg} / \mathrm{l}$ dosage, as shown in Fig. 1. Settling velocities for salt extraction were 0.37 and $0.366 \mathrm{~cm} / \mathrm{min}$ for 2000 and $6000 \mathrm{mg} / \mathrm{l}$, respectively. The defatted MO seeds showed lower settling velocities compared to the salt extract. The settling velocities were $0.35,0.36,0.34 \mathrm{~cm} / \mathrm{min}$ for dosages of 2000,4000 , and $6000 \mathrm{mg} / \mathrm{l}$, respectively. The lowest settling velocities were recorded using crude MO seeds. Settling velocities of $0.33,0.34$, and $0.32 \mathrm{~cm} / \mathrm{min}$ were recorded for dosages of 2000, 4000, and $6000 \mathrm{mg} / \mathrm{l}$, respectively. The control sludge sample recorded a settling velocity of 0.32 $\mathrm{cm} / \mathrm{min}$.

Previous studies also reported the high efficiency of bioactive extraction using $\mathrm{NaCl}$. A study by Okuda et al. showed that the bioactive extraction using salts improved the coagulation efficiency due to the increase in the dissociation of MO proteins, which then led to the increase of the protein solubility in the salt medium. The study also showed that there was no difference in the coagulation efficiency through the extraction of bioactive compounds using $\mathrm{NaCl}, \mathrm{KNO}_{3}, \mathrm{KCl}$, and $\mathrm{NaNO}_{3}$ [14].

The sludge volume index (SVI) is an indicator for characterization of settled sludge. The lower SVI value indicates better settling efficiency. The lowest SVI value of $63.39 \mathrm{ml} / \mathrm{g}$ was obtained using MO salt extraction at $2000 \mathrm{mg} / \mathrm{l}$, as shown in Fig. 2. Unexpectedly, the highest SVI value of $143.34 \mathrm{ml} / \mathrm{g}$ was also for MO salt extraction at a $4000 \mathrm{mg} / \mathrm{l}$ dosage. The defatted MO seeds recorded the lowest SVI value at a dosage of $4000 \mathrm{mg} / \mathrm{l}$. An SVI range of $50-150 \mathrm{ml} / \mathrm{g}$ indicates good sludge-sedimentation properties. The SVI values 
higher than $150 \mathrm{ml} / \mathrm{g}$ indicate that the sludge sedimentation is poor and that there is the possibility of bulking problems [15]. However, the obtained SVI values for all MO forms were in the normal range.

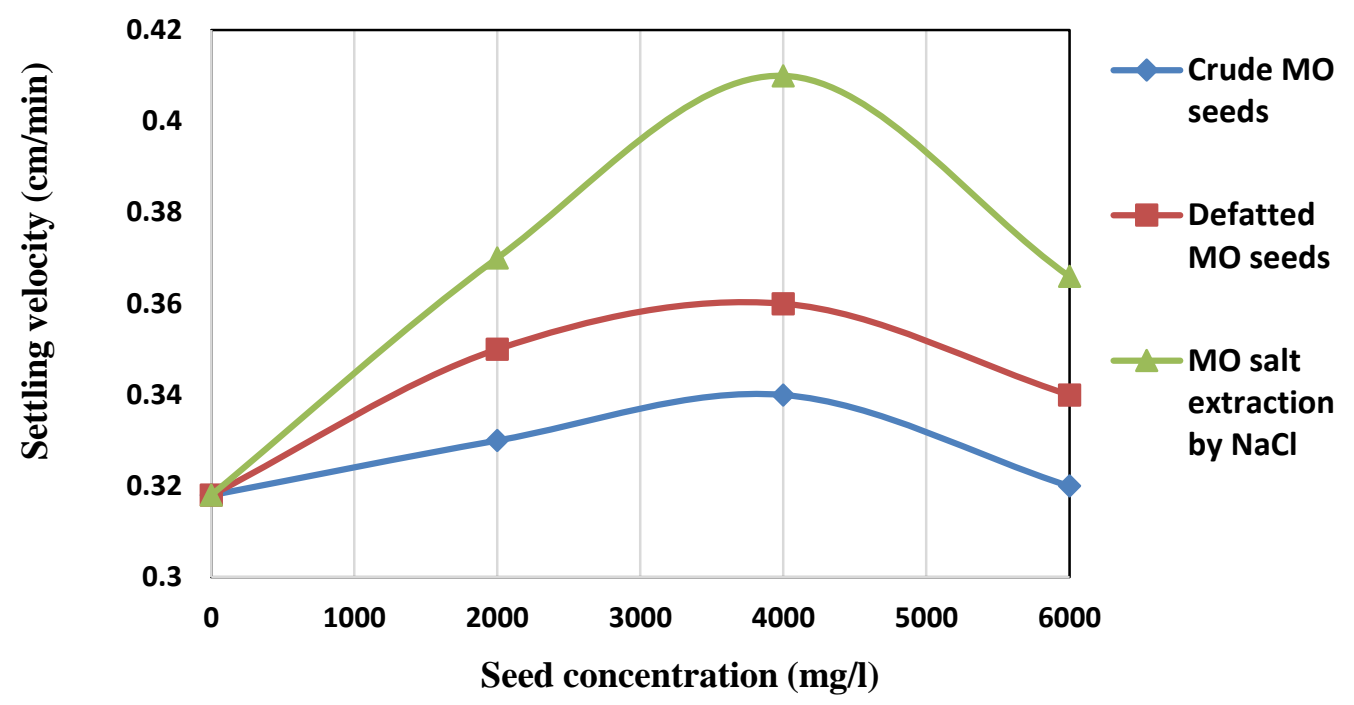

Fig. 1: Different forms of MO seeds and their settling velocities at different dosages.

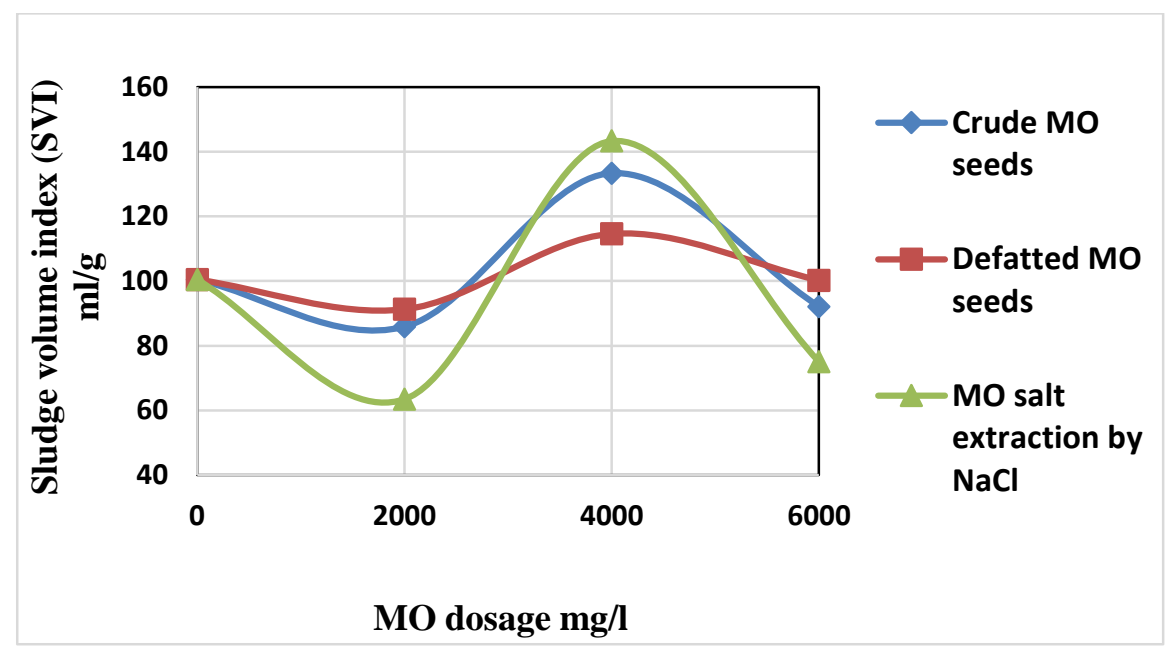

Fig. 2: Different MO coagulant-forms and their SVI values at different dosages.

\subsection{Optimization and Statistical Analysis}

The results of process condition optimization are listed in Table 2. Regression analysis was used to predict the optimal settling velocity using a third order factorial model. The predicted settling velocity was determined through regression model equation developed by Design-Expert software v10. From the experimental results, the highest settling velocity was $0.32 \mathrm{~cm} / \mathrm{min}$ for experiment number 7 under process conditions of $3250 \mathrm{mg} / \mathrm{l}$ dosage, 17.5 minutes of contact time at $100 \mathrm{rpm}$ of mixing speed. The 2D and 3D contour plots of the response surface are the graphical representation of the regression equation used to determine the optimum values of the variables within the ranges considered. The two plots were presented in Fig. 3 and Fig. 4. Each contour curve represents an infinitive number of combinations of the two test variables. 
Table 2: Experimental design for process conditions optimization

\begin{tabular}{ccccccc}
\hline std & Run & $\begin{array}{c}\text { Factor 1 A: } \\
\text { concentration of } \\
\text { seed (mg/l) }\end{array}$ & $\begin{array}{c}\text { Factor 2 B: } \\
\text { contact time } \\
(\mathrm{min})\end{array}$ & $\begin{array}{c}\text { Factor 3 C: } \\
\text { mixing speed } \\
(\mathrm{rpm})\end{array}$ & $\begin{array}{c}\text { Response } \\
\text { Settling velocity } \\
(\mathrm{cm} / \mathrm{min})\end{array}$ & $\begin{array}{c}\text { Predicted } \\
\text { Settling velocity } \\
(\mathrm{cm} / \mathrm{min})\end{array}$ \\
\hline 14 & 1 & 3250 & 17.5 & 150 & 0.31 & 0.31 \\
12 & 2 & 3250 & 30 & 100 & 0.3 & 0.29 \\
6 & 3 & 6000 & 5 & 150 & 0.19 & 0.20 \\
15 & 4 & 3250 & 17.5 & 100 & 0.3 & 0.31 \\
1 & 5 & 500 & 5 & 50 & 0.19 & 0.21 \\
10 & 6 & 6000 & 17.5 & 100 & 0.2 & 0.22 \\
20 & 7 & 3250 & 17.5 & 100 & 0.32 & 0.30 \\
13 & 8 & 3250 & 17.5 & 50 & 0.28 & 0.31 \\
17 & 9 & 3250 & 17.5 & 100 & 0.31 & 0.31 \\
4 & 10 & 6000 & 30 & 50 & 0.28 & 0.28 \\
9 & 11 & 500 & 17.5 & 100 & 0.23 & 0.22 \\
18 & 12 & 3250 & 17.5 & 100 & 0.3 & 0.31 \\
19 & 13 & 3250 & 17.5 & 100 & 0.3 & 0.31 \\
5 & 14 & 500 & 5 & 150 & 0.25 & 0.25 \\
2 & 15 & 6000 & 5 & 50 & 0.22 & 0.22 \\
3 & 16 & 500 & 30 & 50 & 0.23 & 0.22 \\
7 & 17 & 500 & 30 & 150 & 0.24 & 0.25 \\
11 & 18 & 3250 & 5 & 100 & 0.3 & 0.28 \\
8 & 19 & 6000 & 30 & 150 & 0.27 & 0.28 \\
16 & 20 & 3250 & 17.5 & 100 & 0.3 & 0.31 \\
\hline
\end{tabular}

Design-Expert $₫$ Software Factor Coding: Actual Settling velocity $(\mathrm{cm} / \mathrm{min})$

- Design Points

0.32

0.19

$\mathrm{X} 1=\mathrm{A}:$ MO dosage

$\mathrm{X} 2=\mathrm{B}$ : contact time

Actual Factor

C: mixing speed $=100$

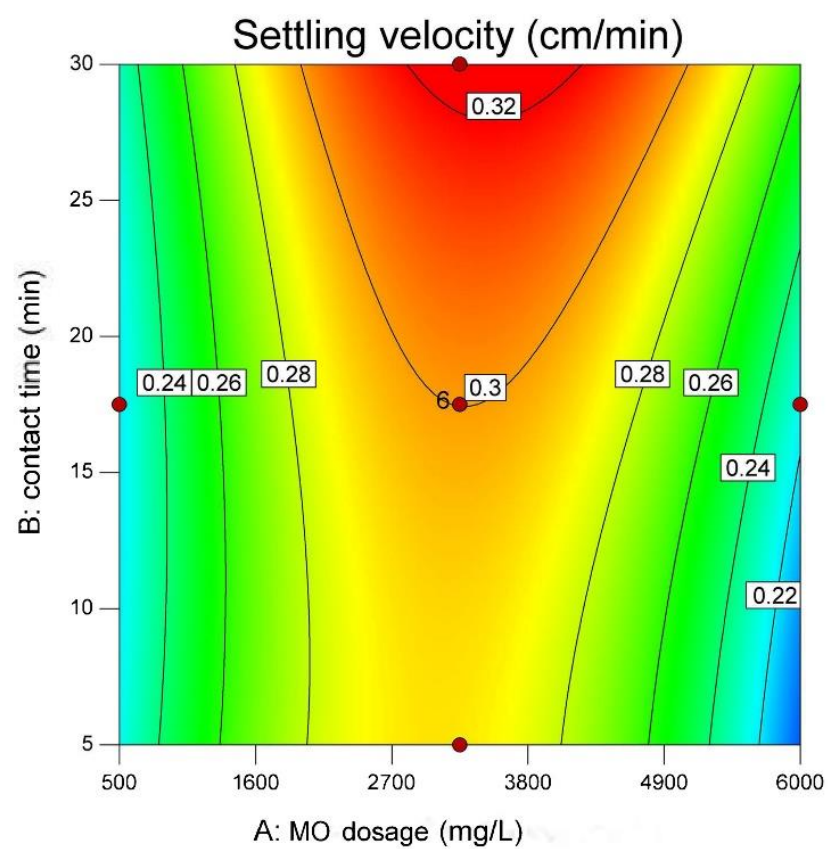

Fig. 3: The 2D contour plot of the interaction of dosage with contact time at mixing speed of $100 \mathrm{rpm}$. 


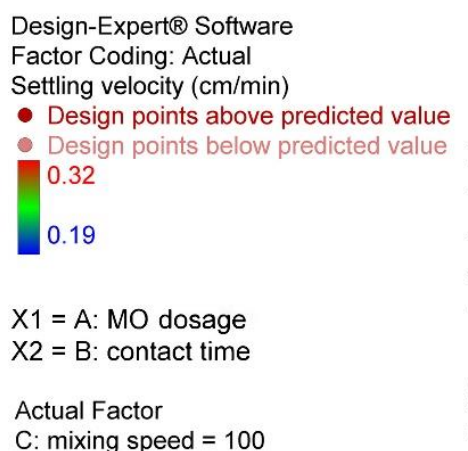

Actual Factor
C: mixing speed $=100$

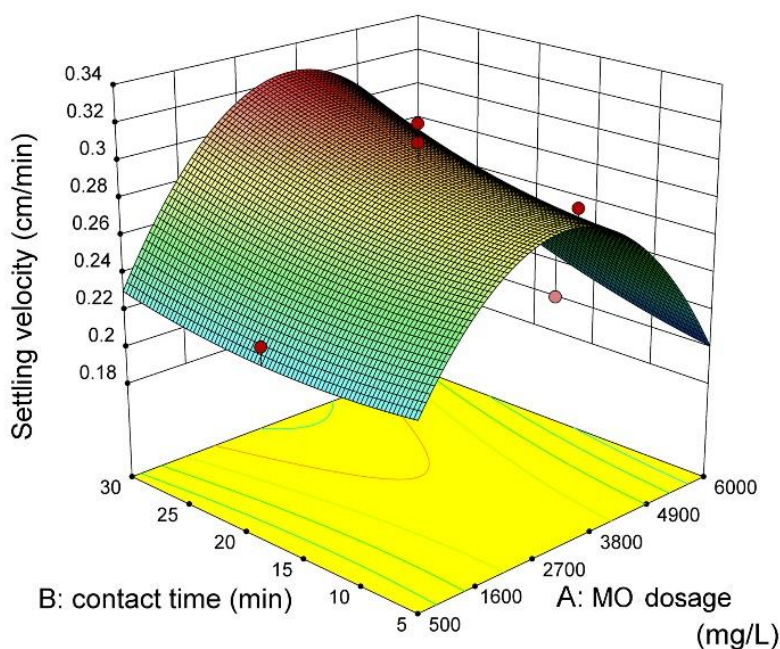

$(\mathrm{mg} / \mathrm{L})$

Fig. 4: The 3D contour plot of the interaction of dosage with contact time at mixing speed of $100 \mathrm{rpm}$.

Figure 5 shows the regression value of actual and predicted settling velocity. Using ANOVA analysis, the Model F-value of 11.65 implies the model is significant. There is only a $0.03 \%$ chance that an F-value this large could occur due to noise. Values of "Prob > F" lower than 0.05 indicate that the model terms are significant. Due to noise, the "Lack of Fit F-value" of 7.88 implies the Lack of Fit is significant. There is only a $2.04 \%$ chance that a "Lack of Fit F-value" this large could occur. The "Predicted R-Squared" of 0.1695 is not as close to the "Adj R-Squared" of 0.8345. The Final Equation, in terms of the actual factors, is:

Settling velocity $=0.15646+7.05342 \times 10^{-5} A-9.69091 \times 10^{-4} B$

$+3.68182 \times 10^{-4} C+4 \times 10^{-7} A B-1 \times 10^{-7} A C-6 \times 10^{-6} B C-1.0278$

$\times 10^{-8} A^{2}+4.65455 \times 10^{-5} B^{2}+9.09091 \times 10^{-7} C^{2}$

Where $A$ is the MO dosage, $B$ is the contact time, and $C$ is the mixing speed.

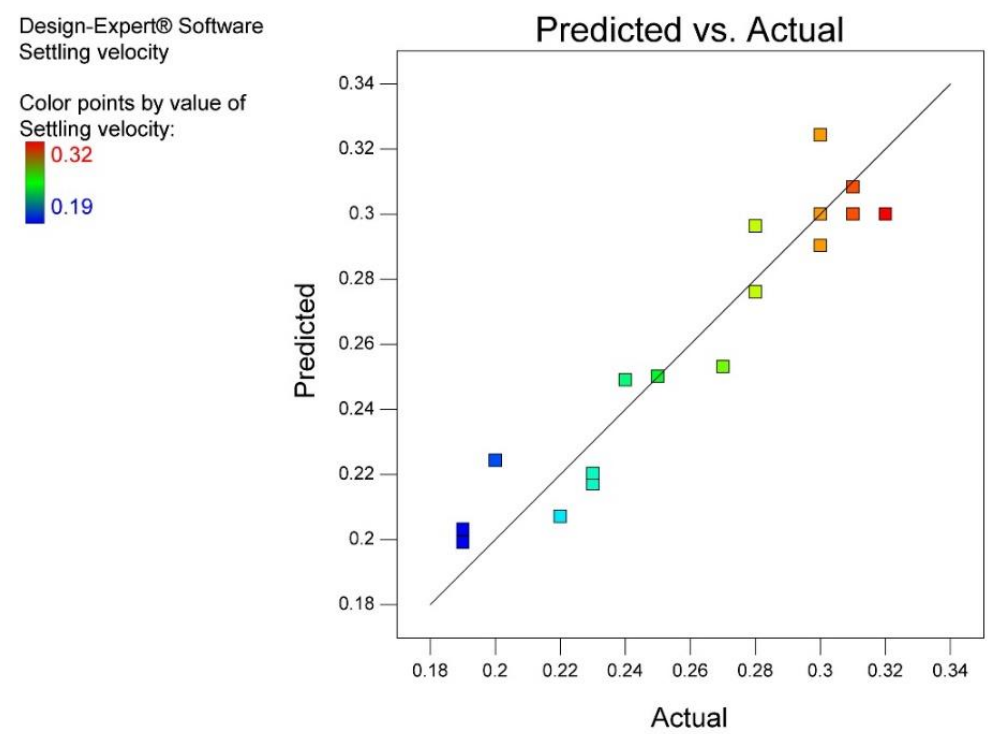

Fig. 5: Regression value of actual and predicted settling velocity. 
Table 3: Regression value and standard deviation

\begin{tabular}{llll}
\hline Std. Dev. & 0.018 & R-Squared & 0.9129 \\
Mean & 0.27 & Adj R-Squared & 0.8345 \\
C.V. \% & 6.63 & Pred R-Squared & 0.1695 \\
PRESS & 0.030 & Adeq Precision & 10.045 \\
\hline
\end{tabular}

From the optimization step, multiple solutions were obtained with a desirability of 1 . The first five solutions were listed in Table 4.

Table 4: Optimization solutions

\begin{tabular}{ccccccc}
\hline No. & $\begin{array}{c}\text { dosage of MO } \\
\text { seeds (mg/l) }\end{array}$ & $\begin{array}{c}\text { contact } \\
\text { time (min) }\end{array}$ & $\begin{array}{c}\text { mixing speed } \\
(\mathrm{rpm})\end{array}$ & $\begin{array}{c}\text { Settling } \\
\text { velocity } \\
(\mathrm{cm} / \mathrm{min})\end{array}$ & Desirability & \\
\hline 1 & 3245.993 & 28.794 & 101.906 & 0.321 & 1.000 & Selected \\
2 & 3641.710 & 27.892 & 52.399 & 0.321 & 1.000 & \\
3 & 4148.779 & 29.743 & 149.907 & 0.321 & 1.000 & \\
4 & 3299.708 & 26.667 & 146.186 & 0.321 & 1.000 & \\
5 & 3474.074 & 29.444 & 125.185 & 0.325 & 1.000 & \\
\hline
\end{tabular}

\section{CONCLUSION}

Different coagulant-forms derived from MO seeds were investigated as sludge conditioners. The $\mathrm{MO}$ coagulant extracted by $\mathrm{NaCl}$ showed the highest settling velocity of $0.41 \mathrm{~cm} / \mathrm{min}$ and lowest SVI of $63.39 \mathrm{ml} / \mathrm{g}$, compared to the crude and defatted MO seeds. Due to the soluble proteins of the MO seed, salt extraction can improve the coagulation efficiency through the salt-in mechanism. The coagulant derived from salt extraction was used in the optimization stage and the optimum process conditions were $3246 \mathrm{mg} / \mathrm{l}, 29 \mathrm{~min}$, $102 \mathrm{rpm}$ for dosage, contact time, and mixing speed, respectively, at an optimum $V_{\mathrm{s}}$ of 0.321 $\mathrm{cm} / \mathrm{min}$. All the coagulant forms showed a significant improvement compared to the control sample. Moringa oleifera can be used as a natural conditioner, and it has the opportunity to be used as a single coagulant or combined with chemical conditioners.

\section{ACKNOWLEDGEMENT}

This work was partially supported by International Islamic University Malaysia, (PRGS 15011-0021) from Ministry of Higher Education of Malaysia.

\section{REFERENCES}

[1] Henderson JP, Heinecke JW. (2003) Waste water treatment and reuse in the mediterranean region. The Handbook of Environmental Chemistry, D. Barcelo and M. Petrovic, Eds Springer, 3:201-214.

[2] Verlicchi P, Zambello E. (2015) Pharmaceuticals and personal care products in untreated and treated sewage sludge: occurrence and environmental risk in the case of application on soil A critical review. Sci. Total Environ., 538:750-767.

[3] Abdul Hamid SH, Lananan F, Khatoon H, Jusoh A, Endut A. (2016) A study of coagulating protein of Moringa oleifera in microalgae bio-flocculation. Int. Biodeterior. Biodegrad, 113:310-317.

[4] LeBlanc RJ, Matthews P, Richard RP. (2008) Global atlas of excreta, wastewater sludge, and biosolids management: moving forward the sustainable and welcome uses of a global 
resource.

[5] Bichi MH. (2013) A review of the applications of Moringa oleifera seeds extract in water treatment. Civ. Environ. Res., 3(8):1-10.

[6] Abdulazeez QM, Jami MS, Alam MZ. (2016) Effective sludge dewatering using Moringa oleifera seed extract combined with aluminium sulfate. J. Eng. Appl. Sci., 11(1):372-381.

[7] Gold M, Dayer P, Faye MCAS, Clair G, Seck A, Niang S, Morgenroth E, Strande L. (2016) Locally produced natural conditioners for dewatering of faecal sludge. Environ. Technol., 37(21):2802-2814.

[8] Kansal SK, Kumari A. (2014) Potential of M. oleifera for the treatment of water and wastewater. Chem. Rev., 114(9):4993-5010.

[9] Hussain J, Jami MS, Muyibi SA. (2012) Enhancement of dewatering properties of kaolin suspension by using cationic polyacrylamide (PAM-C) flocculant and surfactants. Aust. J. Basic Appl. Sci., 6(1):70-73.

[10] Abdulazeez QM, Jami MS, Alam MZ, Iwata M. (2015) Analysis of the efficiency of sludge dewatering using Moringa oleifera as natural phytocoagulant. Int. J. Res. Chem. Metall. Civ. Eng., 2(2):111-117.

[11] Ali EN, Muyibi SA, Salleh HM, Alam MZ, Salleh MRM. (2010) Production of natural coagulant from Moringa oleifera seed for application in treatment of low turbidity water. J. Water Resour. Prot., 2(3):259-266.

[12] Muyibi SA, Alfugara AMS. (2003) Treatment of surface water with Moringa oleifera seed extract and alum- A comparative study using a pilot scale water treatment plant. Intern. J. Environ. Stud., 60(6):617-626.

[13] Yusoff MM, Gordon MH, Ezeh O, Niranjan K. (2016) Aqueous enzymatic extraction of Moringa oleifera oil. Food Chem., 211:400-408.

[14] Okuda T, Baes AU, Nishijima W, Okada M. (1999) Improvement of extraction method of coagulation active components from Moringa oleifera seed. Water Resour., 33(15):33733378.

[15] Turovskiĭ IS, Mathai PK. (2006) Wastewater sludge processing. New Jersey: John Wiley \& Sons, Inc. 